\title{
KIMBERLITES AND ASSOCIATED ROCKS IN THE HOLSTEINSBORG-SØNDRE STRØMFJORD REGION, CENTRAL WEST GREENLAND
}

\section{Arthur Escher and Juan Watterson}

Kimberlites were first found in this region during reconnaissance mapping in 1969 (Escher et al., 1970) and further examples discovered in 1972. Fig. 3 shows the localities of all known intrusions or groups of intrusions regarded as belonging to the suite. Since much of the area has not been examined no conclusions should be drawn from the distribution shown in this figure.

The intrusions are typically dykes, $0.5-2 \mathrm{~m}$ wide, which in the western part of the region strike consistently $100^{\circ}-120^{\circ}$. Attempts have been made to trace only a few dykes, and these persist for distances of at least $1-2 \mathrm{~km}$. A typical dyk contains $20-35 \%$ of rounded ultramafic inclusions ranging in size up to $20 \mathrm{~cm}$, a high proportion of which consist of either olivine alone or olivine plus ilmenite. A sample of 29 nodules from a single dyke examined microscopically showed 16 dunite, 10 harzburgite, 2 wehrlite, 1 lherzolite. As these figures depend to a large extent on the chance presence or absence of a particular pyroxene in a thin section, they are of significance only as an indication of the scarcity of pyroxene in the nodules. Garnetiferous inclusions are abundant only in one dyke (in Holsteinsborg harbour) and this dyke also contains small eclogite inclusions. The groundmass of the dykes consists primarily of carbonate, with olivine, phlogopite, ilmenite, melilite, perovskite and spinel. Two dykes are completely serpentinised, apparently in situ, but the others are almost unaltered, and all dykes are unweathered. Exposure of the dykes is relatively poor owing to solution of the groundmass carbonate.

Other varieties of dyke which have been noted, especially in the western part of the region, include carbonatites which are especially abundant in a major thrust zone $20 \mathrm{~km}$ south-east of Holsteinsborg, and mica peridotites with abundant olivine megacrysts.

Swarms of narrow, up to $5 \mathrm{~cm}$, carbonate veins with abundant rounded olivines have been noted along the coast of Søndre Strømfjord: these are shown separately in fig. 3.

\section{Reference}

Escher, A., Escher, J. [C.] \& Watterson, J. 1970: The Nagssugtoqidian boundary and the deformation of the Kangâmiut dyke swarm in the Søndre Strømfjord area. Rapp. Grønlands geol. Unders. 28, 21-23.

Jane Herdmann Laboratories of Geology, University of Liverpool,

Liverpool 3,

$U . K$. 


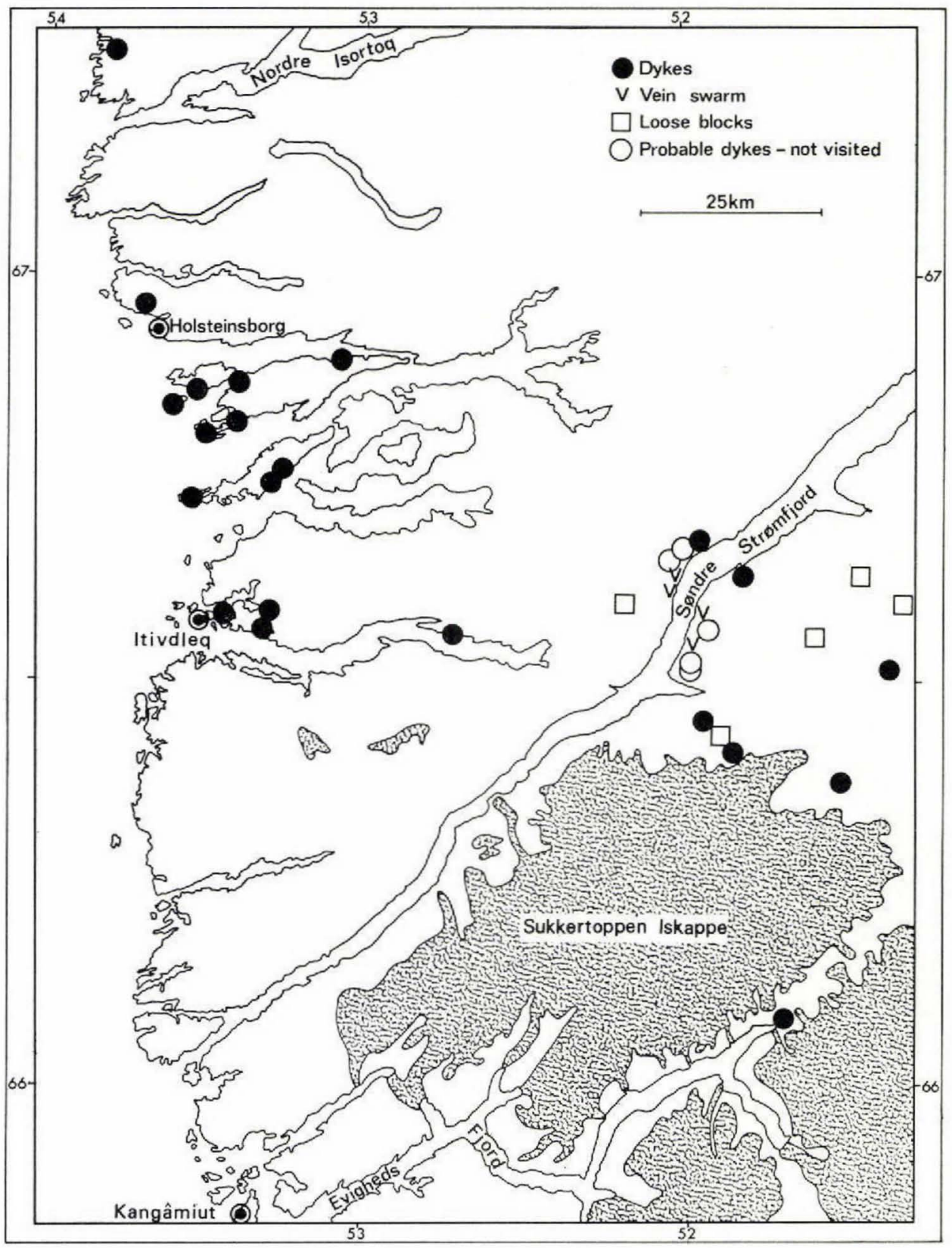

Fig. 3. Localities of minor intrusions of kimberlite and associated rocks in the Holsteinsborg-Kangâmiut region, West Greenland, referred to in the articles by Bridgwater et al., and Escher \& Watterson. 